\title{
Rent Seeking, Nonprofits and Criminal Hubs: The Case of Calabria
}

\author{
Francesco Forte (Corresponding author) \\ Emeritus Professor Department of Public Economics, University of Rome "La Sapienza" \\ E-mail: micros.ricerche@vodafone.it \\ Michela Mantovani \\ Aggregate Professor public finance \\ Department of Law, Economics and History, "Mediterranean” University of Reggio Calabria \\ and \\ Department of Geopedologie, linguistic, statistic History for regional Analysis University of Rome "La Sapienza" \\ E-mail: diocleziana@libero.it \\ Brian Skepys \\ Graduated student Elliott School of International Affairs \\ E-mail: brian.schepis@gmail.com
}

\begin{abstract}
The study concerns rent seeking in the allocation of the Structural Funds for cultural development in the region of Calabria. The Regional planning following the European guidelines was very complex. Own cultural axis, officially oriented to promote tourism, consisted of three measures, each oriented to four goals, with five strategies for each goal and seven specific actions, each articulate in a number of sub-actions, without any clear priority. In the statistical analysis the variables relating to the most important cultural sites had no significance. Rent seeking relating to no profits, to criminal hubs, to construction interests, to employment of people was significant. It may explain the fragmentation of the projects. On the other hand, the presence of the best cultural sites was not important in the disbursement of funds for the criminal hubs. The anomalous discrepancy between allocation of funds and payments also could be explained as a rent seeking phenomenon. The centre-right Government spent funds for investment projects, the centre-left Government devoted funds to service projects and the employment of unskilled labor and intellectual labor.
\end{abstract}

Keywords: Rent seeking, Cultural goods, Tourism, Southern Italy

JEL Classification: H4; R1; Z1

\section{Introduction}

The study examines the rent seeking phenomena arising in the execution of the European Program 2000-2006 for the less developed European regions (so called Objective 1) (Note 1) focusing on the Operational Regional program (POR) of the Region of Calabria, Italy, as for the sector of cultural goods as tourism attractors. (Note 2). The focus on this Program is of particular interest because it was managed by a center-right regional government from 2000 until spring 2005 and by central-left regional government from spring 2005 to the end, so that one also may try to see if the change of Government from the centre right to the centre left has had an effect on the rent seeking. Calabria, (a 2 million inhabitants Region), in Sothern Italy, is rich of cultural sites, dating from the archeological epoch, that are not enhanced and cultural tourism could be an important factor for economic growth. On the other hand Calabria is the headquarter of the most powerful Italian criminal organization of mafia type, i.e. n'drangheta. (Note 3) Independent variables were constructed to capture the main observable sources of rent seeking in the various municipalities: i..e. their voting weight, the presence of no profits and criminal hubs, the presence of members of the Regional junta ruling Calabria. To these variables, was added, the presence in the municipality of important cultural sites, that could have actually justified the allocation of funds. The variable "cultural sites" was crossed with the variable criminal hubs to observe if the allocation of funds of municipalities, hosting these hubs, could be justified by their nature. The variable "type of government" was tested at regional level and observes whether it made difference about project types approved, distinguishing them in investment projects and service projects : the first most popular was about pro business Governments, and the second most popular with Governments interested to sustain employment. It resulted that the most important rent seeking variables (voting weight), no profits, criminal hubs, type of government were relevant, while the variable "cultural sites" was not relevant, both and as a per se variable and in association with the variable criminal hubs.

The study is divided in seven sections. Section 2 provides a brief survey of economic literature on the issues dealt with in the study. Section 3 provides a brief survey of the European Regional Funds Policy, and a detailed exam of 
Calabria 's Regional program 2000-2006 for objective 1, as for the section regarding the culture. It also presents the major cultural sites of Calabria. Section 4 presents information on the statistical methodology adopted. Section 5 provides empirical results documenting the nature and extension of the rent seeking. Section 6 presents the final remarks, policy implications. Section 7 gives some suggestions for future researches.

\section{Survey of literature}

On the EU Structural funds for the regional policies, see Cini (2003) (2007) (2010). The European Community is optimistic about the results of these regional policies, particularly for the less developed Objective 1 regions. See the Commission Staff Working Document 2009. But academic literature on the argument tends to demonstrate disappointing results. Some experts argue that the results are poor in case of regions with weak institutions but in other cases are better than them. A research of Basile, De Nardis, and Berardi of 2001 of ISAE, the Official Economic Research Centre of the Italian Ministry of Economics and Finance, demonstrated that in spite of the huge amount of public aid to the poor regions of EU, the distribution of income, labour productivity and employment rates didn't show a positive relation with the allocation of the EU structural regional funds, in particular in the nineties. Boldrin and Canova (2001) argue that these policies operated mostly as transfer with redistributive and assistance purposes rather than serving as agents to simulate a genuine growth. Puga (2002) observed that, in spite of the large expenditures on European regional policies, economic disparities remained or even widened, mainly because of factors connected with Location Theory. Rodriguez-Pose and Fratesi (2003), showed that the results of the investments in infrastructures and business support were not significant and that just investment in education and human capital had medium term positive and significant returns. Bjorvatn and Coniglio (2006) and Bjorvatn and Coniglio (2007) maintain that (not only in Europe) the policies to promote regional development very often had disappointing results generally, and they connect them with the weakness of the institutions . In many cases, targeted policies create rents that attract rent seekers, so that broad base policies would be more appropriate. More targeted plans should be adopted for regions with strong institutions. A less drastic point of view is that of Cappelen, Castellacci, Fagerberg, and Verspagen (2003) Cappelen, Castellacci, Fagerberg, Vespargen have a less drastic point of view, who substain that EU regional policies had significant positive impact on the growth of less developed European regions, and that the effects are much better in more developed environment. Beugelsdijk and Eijffinger (2005) argue that structural regional funds of the EU have had a positive effect in case of less rich European countries), like Greece, and they add that the most corrupted countries didn't gain less economic growth from the structural funds. They say that many of those who receive the structural funds are not really eligible and, therefore, they use these funds inefficiently. Loddo (2006), with a simplified econometric analysis, argues that the poorer regions in Italy in the 1994-2004 period caught up with the richer regions and that the European structural funds had a role in this convergence. However, agricultural funds had only a transitory positive effect, while the resources allocated had dubious effects for the support of employment, education and human capital in order to the distributional point-of-view. Since the nineties, there has been extensive literature in Italy on the disappointing results of the policies to promote the economic growth of Southern Italy.

On this theme see: Giannola and Imbriani (eds., 2003), Lo Cicero and Reganati (2003), Viesti (2003), Viesti (2009), Viesti and Prota (2009).

V\&V-LSE (2007) shows that, in the period 2000-2001, the Objective 1 regions of Southern Italy grew at the rate of $1.23 \%$ per year while those of the Centre North grew at a rate of $1.24 \%$ and the EU- 15 grew at the rate of $1.96 \%$. According to SVIMEZ (2009) and SVIMEZ (2010), the European and Italian public interventions for the development of Southern Italy, in a large part have failed to reduce the disparities between the Northern and Southern regions, and the regional funds haven't met their objectives. Cancelo, Faina, and Lopez-Rodriguez (2009) substain that EU regional funds have been effective to promote growth in case of Galicia, a Spanish peripheral region of Objective 1. Borbala-Szabo (2007), on the other hand(on the opposite), maintains that in Hungary the EU regional policies impact on economic growth has been disappointing. Ederveen and Gorter (2002), Edereveen, Gortyer and De Mooji (2002) and Ederveen, De Groot and Nahuis (2006) extensive econometric analysis show mixed results from distributive and the growth points-of-view, and they add that impact of these policies on the national policies to reduce regional disparities has been negative. Tugores (2008), considering the EU-15 global macroeconomic results, concludes that the contribution of EU regional policy to the convergence among states is unquestionable in case of Spain, and that they have been a factor of the high growth of Ireland. However, he notices that there hasn't been a convergence among regions inside the states, and he underlines the risk of the resources placed at service of cohesion may wind up in the hands of specific interests through rent seeking.

This point leads to the consideration of rent seeking. Krueger (1974) notices that for less developed economies, rent seeking is the substitute for the missing stimulus of profit seeking. About rent seeking practices in EU regional policies see Bjorvatn and Coniglio (2006) and Bjorvatn and Coniglio (2007), who argue that regional focused policies are fertile ground for rent seeking. Outside the EU, rent seeking in regional policies has been analyzed from 
the point of view of its creation. Zaostrovtseva (2003) viewed it as a negative phenomenon for Russia considering the St. Petersburg region. Golley (2007), regarding Chinese regional policies, argues that rent seeking may be a positive phenomenon, by the economic growth point of view, when there is a "market enhancement" policy with strategies to concentrate public intervention in favour of market in specific areas, but it is negative when there is by-product of extensive and capillary dirigisme. Fisher (2006) connects the perverse effects of rent seeking to growth policies in Africa with institutional weaknesses. On the rich literature on rent seeking after the seminal works of J.M. Buchanan, G. Tullock, and Niskanen see Cogleton, Hillman and Konrad (eds., 2008). According to SVIMEZ (2009) and SVIMEZ (20019), the poor results of the European regional funds come from that a part of them, due to the complexity of the procedures, were not expended before time limit and were diverted to other end and on the opposite because the part was spent with these complex procedures, was not allocated properly.

In the specialized economic literature on cultural goods and tourism there are several contributions that emphasize the importance of the cultural goods as tourism flows attractors. See, for example, Goldoni, Rispoli, and Troncon (eds., 2006), Colbert (2000), Kotler and Scott (1998), Nantel and Colbert (1992), Grossi and Debbia (eds., 1998), Diggles (1986) and Hirshmann (1983). More generally, see Forte and Mantovani (2004). On the specific theme of this research, regional fund policies in the area of cultural goods and tourism development in Southern Italy, the literature is not equally developed. However, see V\&V and LSE (2007), Mantovani (2010) and Ferrari and Cariola (2001).

A more recent analysis on touristic flows, public expenditure on cultural heritages, and Italian regional public policies is in Forte, Magazzino, and Mantovani (2010).

\section{Calabria's POR for cultural goods as attractors of tourism and as endowment of cultural treasuries of Calabria}

The program presented in "Axis II “ of Calabria's POR, is divided in three "measures". Measure 2.1 was devoted to interventions for the preservation and enhancement of cultural heritage the most part of the investments, measure 2.2 to public services for the enhancement of cultural heritage, and measure 2.3 was reserved to entrepreneurial initiatives in the field of cultural heritage. Measure 1 and 3, were both administered by the Regional Department of Tourism because the projects, formally, had to be judged from the point of view of the enhancement of tourism. Cultural tourism is very important for the Italian national economy, but up to this point it has had a very limited role in Calabria. Yet, its main archeological sites, museums and monuments are extremely important at the international level. It has got seven important archaeological parks: Sybaris, Capo Colonna, Solacium, Locri and Monasterace and a major Archeological Museum in Reggio Calabria. In addition, it has got an extremely interesting "defensive system", consisting of castles and towers built by the Normans and others from the ninth century B.C. (consisting of castles and towers, some of them built by the Normans while many others from the ninth century B.C.) Project funds for the development of entrepreneurial initiatives are granted within the limits of the de minimis rule. So that they must be small and the dispersion of the funds is inherent to this part of the program.

The program has been organized by four goals, five programmatic strategies for each goal and seven specific actions, each of them articulate in a number of sub-actions. The sum allocated on the European was 231 million Euro, to which a similar amount was allocated by the Italian Central and Regional Government, a large amount of money for the Calabrian cultural sites, but per se could hardly justify the complex articulation plan . On the other hand, from this construct did not emerged clearly defined priorities. And, due to the complexity of the program, only about one-half of the public funds was actually assigned to projects at the end of 2007.

The four goals are described in an emphatic and vague language as follows.

a) Construction of networks for the enjoyment of cultural and historical heritage, in accordance with already planned network initiatives, and to identify meaningful property at the regional level where to focus project resources in order to conserve, protect, and enhance them.

b) Generate managerial services of both public institutions and private entrepreneurs to meet the demand of residents and tourists for cultural heritage resources.

c) Qualify and support the training of technical and scientific figures tied to the heritage and cultural tourism sector, primarily (especially) for cultural management (organization of cultural institutions and utility companies) and management services for the dissemination of local knowledge (tour services).

d) Develop companies and organizations (public and private, profit and no-profit cultural foundations) relating to the conservation, enhancement, and management of the development of services that combine the benefits of tourism with cultural resources.

Each of the four goals has to be implemented by the following five program strategies: 
a) Concentrating resources around cultural emergencies, identified as key exploitable resources, while preserving and restoring of heritage buildings, archeological site, and geographical landscapes.

b) Enhance regional cultural identities through the wide range of arts, entertainment, and culture for social and economic development.

c) Provide the region with infrastructure resources, such as physical resources, techniques, methods of intervention, advanced services, and other "horizontal" factors such as knowledge and training of cultural heritage.

d) Create an interconnected function system to strengthen the cultural whole (the network of archeological areas, coastal castles, regional libraries, a.s.o.

e) Fostering entrepreneurship in innovated private management services that specialize in the integration between tourism and cultural heritage.

The four program objectives are articulated in five program strategies and they must be realized by seven types of actions.

a) Enhancement of the archeological heritage of Ancient Greece.

b) Establish a network of archeology of the Magna Graecia region for the management, enhancement and protection of archaeological sites and archaeological museums. In particular, the enhancement of the archaeological site of Sybaris is of primary importance.

c) Create theme parks related to archaeological sites through the construction of adequate facilities for their use (Note 4).

d) Recovery, development, and reutilization of the most valuable elements of architectural and landscape heritage (both public and private) for the purpose of establishing infrastructure and equipment aimed at improving and promoting architectural heritage for culture, tourism, local craft, and publishing.

e) Redevelopment of historic centers through the recycling of abandoned buildings for the purpose of cultural tourism, and promoting news business activities in the sector of cultural heritage.

f) Construction of multipurpose centers for the integration of cultural activities and entertainment. These centers must be located in buildings restored as part of the architectural heritage priority.

g) Protection of the landscape through projects aimed at recovery and enhancement of the landscape in both areas of high valued cultural heritage and in areas with projects planned by the regional ecological network (Note 5)

Each action must take into consideration the following six sub-actions.

1. Promotion and implementation of innovative initiatives that enhance the cultural heritage and local identities.

2. Events of significant cultural and anthropological value.

3. Preserving ethnic minorities who have maintained important features of the cultures of origin

4. Activities related to the ancient tradition of craft production, music, the production of pastoral farmers cultural objects, and local foods.

5. Preserving oral traditions.

6. Promotion and creation of cultural networks.

Such kind of program, the rent seeking could find justification in referring to some of the paragraphs of the "economic plan". And (So) the finely targeted economic plan could overlook its true priorities.

The endowment of cultural goods of Calabria, above-mentioned, is very important both in the area of archaeological sites which (that) begin with the pre-Greek era and in that of the ancient castles some of them dating from the 900 a.C. The list of the most important cultural goods that we are going to use here, for the variable cultural sites, consists of a list made by the Italian Ministry of Arts and Cultural Goods (MIBAC) integrated with other cultural sites of notable importance selected by a team of experts of the University of Reggio Calabria. It consists of, among others, old castles still preserved not included in the MIBAC's list, an important Opera Theatre and a cultural centre dedicated to Leonida Repaci a famous Italian writer, who was born in the region, active in the XX century. We have adopted this extended list rather than the MIBAC's list to avoid the possible critics for having considered an ad hoc overly restrictive notion of cultural sites.

\section{Statistical methodology}

This section will employ statistical analysis in order to shed light on the rent seeking variables and the cultural variables that may have determined the allocation of Calabria's POR 2000-2006 Axis II funds devoted to cultural goods as tourism attractors. The dependent variables considered are the number of projects and the amount of Euro 
allocated. The primary (basic) independent variables considered are no-profit institutions, criminal hubs, major cultural sites, and municipalities with a regional government member connection.

Testing was conducted through statistical analysis, including independent sample t-tests and binomial correlations. Independent variables were constructed to capture the main observable sources of rent seeking in the various municipalities. The main considered sources were the municipalities' voting weight, the connection of members of the regional government ruling in Calabria by specific municipalities, and the presence of no-profit organizations and of criminal hubs (Note 6). The presence of important cultural sites was also considered, as an allocation of funds to important cultural sites can be considered justifiable. In qualitative testing, the variable "type of government" was tested to see whether one government favored a type of project instead of others. Projects were distinguished as either construction or service-based: the first that was more popular with pro- business governments and the second that was more popular with governments interests in sustaining employment. The Results showed that the majority of considered rent seeking variables no-profits, criminal hubs, type of government were relevant, while the variable "cultural sites" was not relevant, both in general terms and when they were tested with specific focus on criminal hubs.

Tested projects funded from the POR 2000-2006 Axis 2 and were considered "non continuous" projects, that means they had a specific deadline. This specification allowed for simplified testing and analysis. Testing was comprised of bivariate correlations and two independent simple t-tests, which compares variable means of two data categories. All statistical significances were taken at a $95 \%$ confidence level.

In order to attain a thorough statistical depiction of the fund allocation correlations and t-tests were organized into two primary levels of analysis. The first is the municipal level. Each case corresponded with one of the 409 Calabria's municipalities that were able to receive funds. (Note 7) This type of research allows us to know why some municipalities got projects and others did not. The second is the project level. Here we also test which variables influenced the kind of project, which were construction-related investment projects and service projects.

The variables considered were population (Note 8), the number of major cultural sites in cultural hubs, which were municipalities with at least one major cultural sites (see Table A), the number of no-profit institutions (Note 9), project imports, project payments, the number of projects (Table D ), the percent vote to the winning presidential party in the 2000 and 2005 regional elections (in the Regional Election 2000 and 2005) (Note 10), criminal hubs (see Table G), Chiaravalloti (centre-right party) regional government connection and Loiero (centre-left party) regional government connection (Note 11). The municipality "government connection" variable was attributed to any municipality that was the hometown of a member of the regional government. The dependent variables of the analysis were imports, payments, and projects. It is important To distinguish "imports" the initially planned amount of euro allocation to a single projects), and "payments" the final amount actually disbursed to a project because many projects failed to move past their initial stage and therefore received only a share of the planned import as its final payment.

\section{Empirical Results}

The tests (see Table B) showed that imports, payments, projects, and no-profit institutions were positively correlated with population. So, in order to eliminate the Bias caused by the size of the population of the various municipalities, while the remaining tests were conducted in per capita terms.

Statistical analysis showed that cultural sites were not major influencers of fund allocation. Table B-C tests 5-6 tested for correlations between imports, payments, and projects per capita and number of cultural sites. There was no correlation between these variables. The lack of connection between cultural sites and fund allocation was further established with tests 7-11, which were a series of t-tests at both the municipal and project levels. The tests found that cultural hubs did not receive significantly higher projects per capita, and that projects within cultural hubs did not receive significantly higher imports or payments than those in non cultural hubs. The only variable that was statistically significant was imports at the project level for construction-related investment projects, but payments at the same level and for the same type of projects, on the other hand, were not statistically significant. This means that while it was originally planned for cultural hubs to receive significantly more euro for investment projects more than for non cultural hubs, in the end, the planned construction-related investment projects in cultural hubs had a higher chance of remaining incomplete. On average, in fact, non cultural hubs municipalities received $68 \%$ of the initial imports in payment while cultural hubs received only $45 \%$. This may have been due to errors in the conceptions of the projects, mismanagement or lack of initiative in pursuing the given objectives. Morally hazardous behavior to get the first project payment may also provide an explanation because the project's private counterpart had to participate in a pre-groundbreaking feasibility study and provide preliminary services.

Rent seeking by no-profit institutions proved to be important to the allocation POR funds. Tests 12-14 in Table C show that imports, payments, and projects per capita were all highly correlated with the no-profit per capita. In 
other words, in the municipalities with the higher number of no-profit per capita, there was a higher amount of funds allocated and disbursed. The number of projects was also correlated with the number of no-profits that is should be a logical result if the competition among no-profits reaches its end with a dispersion of the funds in many small projects in favor of an high number of rent seekers in the attempt by the politicians and the bureaucrats to minimize any discontent. This result is confirmed by the regression of the municipalities that received funds that shows a negative relation between the presence of no-profits and the amount per capita

At first sight, it appears that criminal hubs did not impact decisions for POR funding. The test, for the municipalities that obtained projects, did not show a preference for criminal hubs in comparison with the municipalities without criminal that obtain hubs, as for the imports and payments per capita (see Table D in Appendix, in the section on "Municipalities that obtained projects. But, looking at the data in Table D, in the "All Municipalities" section it is evident that criminal hubs as a whole received per capita more imports and payments per capita on average than all the other Calabria's municipalities. Per capita, the amount obtained by the subset of "all municipalities" with criminal hubs, was 113.64 euro instead of the subset of " all municipalities" without criminal hubs that was about 83.73 euro. The results are similar for the amount actually spent. And an analogous result there was for the share of the 409 Calabria's municipalities that received funds on Axis II for Culture, of the Calabria's POR of the 72 Calabria's municipalities with criminal hubs, those who obtained funds were 54 i.e. $75 \%$. Of the 337 Calabria's municipalities without criminal hubs, 156 i.e. a mere 46,29\% obtained projects (see Table D in the section on "Municipalities that obtained projects"). ). Also as for the assignment of the 539 projects, the municipalities with criminal hubs were preferred. Indeed 259 projects i.e. 48,05\% were assigned to municipalities with criminal hubs representing $17,6 \%$ of the total while 287 i.e, $51,09 \%$ were assigned to the municipalities without criminal hubs representing $82,40 \%$ of the total.

Considering, now, the municipalities that obtained projects in Table $\mathrm{D}$, one of them is struck by the huge difference between the criminal hubs and the other municipalities, both of them for the total amounts committed and paid to them and for the amounts per project. As we can see, Criminal hubs obtained an amount of funds 4 times greater than the other municipalities. And the payments to them were 3,86\% greater. The average amount committed for the 539 projects approved on this Axis II for Culture was about 365,490 euro. However for the 259 projects assigned to municipalities with criminal hubs it was about 444,000 euro $(122 \%$ higher than the average). For the municipalities without criminal hubs was only 290,290 (79\% of the average) As for the payments received, the average amount per project was 291,280 euro. For the municipalities with criminal hubs it was 357,143 euro (119\% higher than the average), while for the other municipalities it was 233.445 euro (about $82 \%$ of the average). The greater difference between the ratio of the amounts committed and the amounts paid in the municipalities with criminal hubs as compared with the other municipalities, is due to the grater relevance of unfinished projects. One way of profiting from the European funds consisted of minimizing the co-financing component, which was possible through leaving incomplete the investment projects.

Considering now the section of Table D on the Criminal Hubs-Municipalities with or without cultural sites, we can see that out of the 259 projects assigned to these municipalities only 39 were given to municipalities with cultural sites. On the other hand the amount committed to them was 62 million as against the 53 to all the other projects in these municipalities. So that the share for the cultural sites was about $54 \%$. However this partial readjustment in favor of the cultural sites disappears when we consider the amounts actually spent: 38 million for the municipalities with cultural sites and 52 for the other municipalities. So that we can conclude that the cultural sites in the municipalities with criminal hubs were damaged rather than helped by this Por, because many of the projects for them remained unfinished.

Tests 19-32 (Tables E) all concluded with negative results, which suggests that there are no statistically significant differences between Loiero and Chiaravalloti government connected municipalities compared to other municipalities. These results applied from import, payment, projects, and no-profits per capita at the municipal level to imports and payments for construction-related investments and service projects at the project level.

However, it was found that the Chiravalloti's government allocated all of the funds dedicated to Measure 2.1 projects and that the Loiero government allocated at least $76 \%$ of Measure 2.2 projects. (Note 11) So, this strongly suggests that the Chiaravalloti had an agenda for investment projects over service projects. Loiero government (Table F) had an agenda for service projects.

Regarding construction-related investment projects, only $58.4 \%$ of the initial import was ultimately awarded. Service projects, where there was no co-financing by the beneficiaries, experienced an higher final payment percentage of the initial imports $(81.3 \%)$. The fact that the entire amount was not disbursed probably means that many of these projects did not appear serious enough to be financed until their completion.

\section{Concluding remarks and policy implications}


As the empirical analysis showed, there is a significant statistical relation between the presence of no-profits in the different municipalities and the allocation of the projects both as for their imports and payments. But, in considering the municipalities that received funds, the regression shows a negative relation between the presence of no-profits and the amount per capita. Likely the competition among these rent seekers has reduced the per capita amounts of the funds received in their municipalities, in the attempt of public authorities of accommodating most of them to the table of the beneficiaries. Thus one may argue that rent seeking of the local pressure groups has been an important factor in the dispersion of funds, which also results in the deviation from their proper objectives to promote the important cultural sites and to employ them in cultural projects that may function as attractor of tourism.

Criminal hubs seem to have been relevant as for the distribution of the funds as the municipalities while criminal hubs have received a greater amount of funds and projects than the other municipalities. There has been a large spread between allocation and payments. In this way, the beneficiaries of the projects extracted a greater benefit from their rent seeking activity, because minimized their co-financing. On the other hand there wasn't a predominance for the expenditure for the cultural sites in the criminal hubs. And the Region has not promoted a policy for the enhancement of the cultural level of the criminal hubs.

While there is no significant statistical relation between the municipalities of residence of the members of the centre right or the centre left juntas, rent seeking appears to emerges as for the significant difference in the allocation of funds by the two Regional Governments. The centre-right Government spent the funds mostly for investment projects in construction.. This kind of industry is one of the most important in a region as Calabria and it is likely to exert a particular influence on a centre-right political coalition. The centre-left Government devoted the funds to service projects and the unemployment of both unskilled labor and intellectual labor is another characteristic of the region. And employment policy is a priority for governments leaning to the left. It should be noted that this increase of employment is only temporary and that the investment policies in cultural projects were to a large extent wasted because a share of them remained unfinished and because no priority had been observed on the allocation of the funds. Indeed, as noted, no statistical relation has been found between the allocation of the funds and the major cultural sites and there has not been a preferential allocation of the funds as for the important cultural sites present in the criminal hubs.

\section{Suggestions for future research}

There is a strong need for further research on rent seeking practices in the allocation of European Structural Funds in general, and in Italy in particular. Indeed, as the literature shows, these ambitious programs failed their convergence objective to a large extent, particularly in the underdeveloped regions of developed countries like Italy. One of the most important reasons of this failure is that this type of planning might give rise to rent seeking and other related anomalies in research management.

\section{References}

Basile Roberto, Nardis Sergio and Girardi Alessandro (2001). Regional Inequalities and Cohesion. Policies in the European Union, ISAE Working Paper, No. 23.

Beugelsdijk Maaike \& Sylvester C.W., Eijffinger. (2003). The effectiveness of Structural Policy in the European Union: An Empirical Analysis for the EU-15 in 1996-2001, in "Journal of Common Market Studies", Vol. 43, No. 1.

Bjorvatn K. Kjetil \& Nicola Daniele Coniglio. (2006). Policy Design and Rent Seeking. Targeted versus Broad Based Interventions, in "Review of Development Economics", Vol. 10, No. 4, pp. 577-585.

Bjorvatn K. Kjetil \& Nicola Daniele Coniglio. (2007). How Should Industrial Policy be Designed in Developing Countries, S.E.R.I.E.S. Working Paper, No.14.

Borbalá Szabó. (2007). EU Programs and Funds and their Impact on the Development of the Hungarian Economy, euconsent.net.

Josè Ramos Cancelo de la Torre, Andres Faína, Jesus López-Rodríguez. (2009). Measuring the Permanent Impact of European Structural Funds on Peripheral Objective 1 Regions: The Case of Galicia, in "European Planning Studies", Vol. 17, No. 10, October, pp. 1535-1558.

Cappelen Aadne, Castellacci Fulvio, Jan Fagerberg, Bart Verspagen. (2003). The Impact of EU Regional Support on Growth and Convergence in the European Union, in "Journal of Common Market Studies", Vol. 41, No. 4, pp. 641-644.

Samprit Chatterjee and Ali S. Hadi (2006). Regression Analysis by Example, Wiley, New York.

Cini Michelle (2007). European Union Politics, Oxford University Press, Oxford.

Colbert Francois, Nantel Jaques, Bilodeau Suzanne. (2001). Marketing Culture and the Arts, HEC Montreal, $2^{\text {nd }}$ Edition 
Cole Ismail M.,M. Arshad Chawdhry, (2002). Rent Seeking and Economic Growth: Evidence from a Panel of EU States, in "The Cato Journal", Vol. 22, No. 2.

Commission of the European Communities. (2009). Commission Staff Working Document. Accompanying the $20^{\text {th }}$ Annual Report of implementation of the structural funds(2008). Commission of the European Communities, Brussels.

Congleton Roger, Hillman HArvey, Konrad Kai. A. (eds., 2008). Forty Years on Research on Rent Seeking, Springer, Berlin.

Cook Richard. (1977). Detection of influential observations in linear regression, in "Technometric", 19, pp. 15-18.

Dreger Christian, Teymur Rahmani,Hans-Friedrich Eckey. (2007). Economic Convergence and Rent Seeking in Iran, DIW Discussion Paper, No. 741.

Ederveen Sief, Henry de Groot, Richard Nahuis. (2006). Fertile soil for Structural Funds? A panel data analysis of the conditional effectiveness of European cohesion policy, in "Kyklos", Vol. 59, No. 1, pp. 31-55.

Ederveen Sief., Ruud de Mooij, John Gorter, and Richard Nahuis. (2002). Funds and games: The economics of European cohesion policy, CPB Discussion paper No. 3.

Ederveen Sief., John Gorter. (2002). Does European cohesion policy reduce regional disparities? An empirical analysis, CPB Discussion paper No. 15.

European Commission (1997). Agenda 2000 for a stronger and wider Union, Commission of the European Communities, Brussels.

European Commission (2001). Unity, solidarity, diversity for Europe, its people and its territory. Second Report on Social Cohesion, Commission of the European Communities, Brussels.

European Union Regional Policy (2008). Cohesion Policy 2007-2013. National Strategic Reference Frameworks, Commission of the European Communities, Brussels.

Fischer Pius. (2006). Rent-Seeking, Institutions and Reforms in Africa, Springer, Berlin.

Forte Francesco, Mantovani Michela. (2004). Manuale di economia e politica dei beni culturali, Rubbettino, Soveria Mannelli.

Forte Francesco, Mantovani Michela. (2009). Cooperatives' Tax Regimes, Political Orientation of Governments and Rent Seeking, in "Journal of Politics and Law", Vol. 2, No. 4, December, pp. 44- 57.

Forte Francesco, Magazzino Cosimo Mantovani Michela. On the failure of European planning for less developed regions. The case of Calabria. in Backaus J. editor,2010, Finanzsoziologie 3, Frankfurt, Peter Lang

Diggle Keith. (1986). Guide to Arts Marketing: the Principles and Practice of Marketing as They Apply to Arts, Rhinegold, London.

Gelauff George, Grilo Isabel, Lejour Arjan. (eds., 2008). Subsidiarity and Economic Reform in Europe, Springer, Berlin.

Gelauff George, Grilo Isabel, Lejour Arjan. (eds., 2008). Subsidiarity and Economic Reform in Europe. (2005). Europe's financial perspectives in perspective, CPB document 101.

Goldoni Daniele, Rispoli Murizio, Troncon Renato. ( 2006). Estetica e management nei beni e nelle produzioni culturali, Il Brennero, Bolzano.

Golley Jane. (2007). The Dynamics of Chinese regional development: market nature, state nurture, Edward Elgar, Cheltenham.

Grossi Roberto., Debbia Stefania. (eds., 1998). Cantiere Cultura. Beni Culturali e Turismo come risorse di sviluppo locale, Federculture/Il Sole-24Ore, Milano.

Gratteri Nicola, Nicaso Antonio. (2006). Fratelli di sangue, Pellegrini, Cosenza.

Hirshmann E. C. (1983). Aesthetics, Ideologies and the Limits of the Marketing Concept, in "Journal of Marketing", Vol. 47, Summer.

Imbriani Cesare, Giannola Adriano. (eds., 2003). Neo-dualismo: Istituzioni, mercati e politiche di intervento, Rubbettino, Soveria Mannelli.

Kotler Phillip,Keller Kevin (2009) Marketing Management, 13th edition,. Prentice Hall Englewood Cliff N.J

Lo Cicero Massimo, Reganati Filippo. (2003). L'economia del Mezzogiorno d'Italia. Nuovi caratteri del dualismo e le variabili per misurarlo, in Imbriani Cesare. and Giannola Adriano. (eds.). 
Loddo Salvatorangelo. (2006). Structural funds and regional convergence in Italy, CRENoS Working Paper, No. 3.

Mantovani Michela. (2006). Alcune riflessioni sulla politica fiscale per i distretti turistici e culturali, in AA. VV., Annali 2006 del Dipartimento di studi Geoeconomici, Linguistici, Statistici, Storici per l'Analisi Regionale, Facoltà di Economia - Università degli Studi di Roma "La Sapienza".

Mantovani Michela. (2008). Lezioni di economia pubblica dei beni culturali, Giappichelli, Torino.

Mantovani Michela. (2010). Le politiche regionali della Calabria per i beni culturali e nel quadro degli incentivi dell’UE 2000-2006, in Spadaro Antonino. (ed.).

Nantel Jaques. A., Colbert Francois. (1992). Positioning cultural arts products in the market, in "Journal of Cultural Economics”, Vol. 16, No. 2, December, pp. 63-71.

Puga Diego. (2002) European regional policies in light of recent location theories, in "Journal of Economic Geography", No. 2, October, 2002, 373-406.

Rodriguez Pose Andres, Fratesi Ugo. (2003). Between development and social policies: the impact of European Structural Funds in an Objective 1 regions, Grupo de Economia Europea, Working Paper N. 28.

Spadaro Antonino. (2010). Istituzioni e proposte di riforma. Un progetto per la Calabria, Jovene, Napoli.

Svimez. (2009). Rapporto 2009 sull'economia del Mezzogiorno, Il Mulino, Bologna.

Svimez. (2009). Dopo il rapporto Svimez 2009: Una riflessione per rilanciare la politica di sviluppo del Sud, Quaderno Svimez, No. 24, Svimez, Roma.

Svimez. (2010) bis, Rapporto Svimez 2010 sull'economia del Mezzogiorno, Il Mulino, Bologna

Tugores Joan. (2008). Regional integration and public policy. Evaluation of the European experience and possible implications for Latin America integration, in "Etudios y perspectivas", No. 65.

Van der Beek Gregory, Neal Larry (2004). The Dilemma of Enlargement for the European Union's Regional Policy, in "The World Economy", Vol. 27, No. 4, April, pp. 587-607.

Viesti Gianfranco. (2003). Abolire il Mezzogiorno, Laterza, Roma-Bari.

Viesti Gianfranco. (2009). Mezzogiorno a tradimento. Il Nord, il Sud e la politica che non c'è, Laterza, Roma-Bari.

Viesti Gianfranco, Prota Francesco. (2009). Le politiche regionali dell'Unione Europea, Il Mulino, Bologna.

Vision \& Value, London School of Economics. (2007). EU Structural Funds and Economic Development of Southern Italy, LSE, London.

Zaostrovtsev A. (2003). Rent-Seeking Versus Rent-Setting: Government versus Competition. The Case of St. Petersburg, in Lane T. D., Oding N., Welfens P. J. J. (eds.). Real and financial dynamics in Russia and eastern Europe, Springer, Berlin.

\section{Notes}

Note 1. under the Community Support Framework (CSF)

Note 2.Axis II of Calabria's POR 2000-2006

Note 3.The name ndrangheta is a corruption of the ancient Greek expression Andros Agathos, which means men of honor. Actually the original stronghold of ndrangheta is in an area of Calabria where the ancient Greek dialect is still spoken.

Note 4.These three actions must be accomplished through:

1. Feasibility studies and implementation projects.

2. Rehabilitation of archeological sites and the restoration of museums and artifacts.

3. Assistance for the construction of infrastructure and facilities.

4. Architectural Heritage and Landscape.

Note 5. This measure supports the implementation of initiatives of national importance and visibility, realized by partnerships of public and private agencies that promote cultural heritage regional and local identities, to attract flows of cultural tourism.

Note 6. Criminal hubs were considered any municipality that is known as stronghold for organized criminal activity. The list official comes from the Nicola Gratteri study Fratelli di Sangue.

Note 7.The data set available in the web site of the Calabria's Region .

Note 8.ISTAT DAWINCI Database. 
Note 9.ISTAT DWCIS Database..

Note 10. Ministero dell'Interno Election Archives.

Note 11.Region of Calabria Website. Giunta Page.

Table A. Cultural Sites of Calabria by Municipality and Province

\begin{tabular}{|c|c|c|}
\hline Cultural Site & Municipality & Province \\
\hline 1. Archeological park of Scolacium & BORGIA & \multirow{3}{*}{ CATANZARO } \\
\hline 2. Archeological Museum of Lamezia (Neolithic) & LAMEZIA TERME & \\
\hline 3. Norman Castle & SQUILLACE & \\
\hline 4. State Archeological Museum & AMENDOLARA & \multirow{9}{*}{ COSENZA } \\
\hline 5. Archeological Park of Sibari & CASSANO ALL'IONIO & \\
\hline 6. Sibarite's National Archeological Museum & CASSANO ALL'IONIO & \\
\hline 7. Cosenza's National Gallery & COSENZA & \\
\hline 8. Norman Swew Castle & COSENZA & \\
\hline 9. Antiquarium of Scalea - Torre Cimalonga & SCALEA & \\
\hline 10 Norman Castle & CORIGLIANO & \\
\hline 11. Maritime Aragon Castle & BELVEDERE & \\
\hline 12. Swew Castle & ROSETO & \\
\hline 13. Pathirion & ROSSANO & \multirow{5}{*}{ CROTONE } \\
\hline 14. Nao Tower & CROTONE & \\
\hline 15. National Archeological Museum & CROTONE & \\
\hline 16. Le Castella & ISOLA DI CAPO RIZZUTO & \\
\hline 17. Norman Castle & SANTA SEVERINA & \\
\hline 18. Church of Saint Francis of Assisi & GERACE & \multirow{12}{*}{ REGGIO DI CALABRIA } \\
\hline 19.Church of Saint Giovannello & GERACE & \\
\hline 20. "Centocamere" Archeological area & LOCRI & \\
\hline 21. Greek Roman Theater & LOCRI & \\
\hline 22.National Archeological Museum & LOCRI & \\
\hline 23. Archeological area & MONASTERACE & \\
\hline 24.Leonida Repaci' s Cultural house & PALMI & \\
\hline 25.Aragon Castle & REGGIO DI CALABRIA & \\
\hline 26. Cilea’s Municipal Theater & REGGIO DI CALABRIA & \\
\hline 27. National Archeological Museum & REGGIO DI CALABRIA & \\
\hline 28. The Catholic ((La Cattolica) & STILO & \\
\hline 29. Ruffo' Castle & SCILLA & \\
\hline 30. State Museum & MILETO & \multirow{6}{*}{ VIBO VALENTIA } \\
\hline 31. National Archeological Museum & VIBO VALENTIA & \\
\hline 32. Norman Swew Castle & VIBO VALENTIA & \\
\hline 33. Murat's Museum & PIZZO & \\
\hline 34. Murat Castle & PIZZO & \\
\hline 35. Cistercensis Convent & SERRA SAN BRUNO & \\
\hline
\end{tabular}

Source: University of Reggio Calabria: Department of Law, Economics and History

Table B.Test Details for Variables Requiring Controlled Testing at the municipal Level

\begin{tabular}{|c|c|c|c|c|c|c|c|c|}
\hline $\begin{array}{l}\text { Test } \\
\# \\
\end{array}$ & Level & Focus & Test & $\begin{array}{c}\text { Variables } \\
\text { Tested } \\
\end{array}$ & Mean & $\begin{array}{l}\text { Standard } \\
\text { Deviation }\end{array}$ & Conditions & Significance \\
\hline \multirow{2}{*}{1} & \multirow{2}{*}{ MUNICIPAL } & \multirow{2}{*}{ Overall } & \multirow{2}{*}{ Correlation } & Import & 263652.8773 & 829885.251 & \multirow{2}{*}{$\begin{array}{c}\mathrm{r}(407)=.649, \\
\mathrm{p}<.001\end{array}$} & \multirow{2}{*}{ Yes } \\
\hline & & & & Population & 4918.00978 & 12191.92501 & & \\
\hline \multirow{2}{*}{2} & \multirow{2}{*}{ MUNICIPAL } & \multirow{2}{*}{ Overall } & \multirow{2}{*}{ Correlation } & Payment & 168793.3095 & 578977.2679 & \multirow{2}{*}{$\begin{array}{c}\mathrm{r}(407)=.644, \\
\mathrm{p}<.001\end{array}$} & \multirow{2}{*}{ Yes } \\
\hline & & & & Population & 4918.00978 & 12191.92501 & & \\
\hline \multirow{2}{*}{3} & \multirow{2}{*}{ MUNICIPAL } & \multirow{2}{*}{ Overall } & \multirow{2}{*}{ Correlation } & Nonprofits & 15.84596577 & 53.43984376 & \multirow{2}{*}{$\begin{array}{c}\mathrm{r}(407)=.947 \\
\mathrm{p}<.001\end{array}$} & \multirow{2}{*}{ Yes } \\
\hline & & & & Population & 4918.00978 & 12191.92501 & & \\
\hline \multirow{2}{*}{4} & \multirow{2}{*}{ MUNICIPAL } & \multirow{2}{*}{ Overall } & \multirow{2}{*}{ Correlation } & Projects & 0.750611247 & 1.834154683 & \multirow{2}{*}{$\begin{array}{c}\mathrm{r}(407)=.773, \\
\mathrm{p}<.001\end{array}$} & \multirow{2}{*}{ Yes } \\
\hline & & & & Population & 4918.00978 & 12191.92501 & & \\
\hline
\end{tabular}

Source: our calculations 
Table C. Test Details for Cultural Sites and Nonprofit Institutions

\begin{tabular}{|c|c|c|c|c|c|c|c|c|c|}
\hline $\begin{array}{l}\text { Test } \\
\#\end{array}$ & Level & Focus & Test & Groups & $\begin{array}{l}\text { Variables } \\
\text { Tested }\end{array}$ & Mean & $\begin{array}{l}\text { Standard } \\
\text { Deviation }\end{array}$ & Conditions & Significance \\
\hline \multirow{2}{*}{5} & \multirow{2}{*}{ MUNICIPAL } & \multirow{2}{*}{ Overall } & \multirow{2}{*}{ Correlation } & \multirow{2}{*}{ N/A } & $\begin{array}{l}\text { Import per } \\
\text { capita }\end{array}$ & 76.65711571 & 349.0121898 & \multirow{2}{*}{$\mathrm{r}(407)=.051, \mathrm{p}=.301$} & \multirow{2}{*}{ No } \\
\hline & & & & & $\begin{array}{l}\text { Cultural } \\
\text { Sites }\end{array}$ & 0.083129584 & 0.361008915 & & \\
\hline \multirow[t]{2}{*}{6} & \multirow[t]{2}{*}{ MUNICIPAL } & \multirow[t]{2}{*}{ Overall } & \multirow[t]{2}{*}{ Correlation } & \multirow[t]{2}{*}{ N/A } & $\begin{array}{l}\text { Payment } \\
\text { per } \\
\text { capita }\end{array}$ & 50.17762088 & 169.7859754 & \multirow[t]{2}{*}{$\mathrm{r}(407)=.023, \mathrm{p}=.638$} & \multirow[t]{2}{*}{ No } \\
\hline & & & & & $\begin{array}{l}\text { Cultural } \\
\text { Sites }\end{array}$ & 0.083129584 & 0.361008915 & & \\
\hline \multirow[t]{2}{*}{7} & \multirow[t]{2}{*}{ MUNICIPAL } & \multirow[t]{2}{*}{ Overall } & \multirow[t]{2}{*}{ Correlation } & \multirow[t]{2}{*}{ N/A } & $\begin{array}{l}\text { Projects } \\
\text { per } \\
\text { capita }\end{array}$ & 0.000239162 & 0.000842168 & \multirow[t]{2}{*}{$\mathrm{r}(407)=.012, \mathrm{p}=.805$} & \multirow[t]{2}{*}{ No } \\
\hline & & & & & $\begin{array}{l}\text { Cultural } \\
\text { Sites }\end{array}$ & 0.083129584 & 0.361008915 & & \\
\hline \multirow{8}{*}{8} & \multirow{8}{*}{ MUNICIPAL } & \multirow{8}{*}{ Overall } & \multirow{8}{*}{ T-Test } & \multirow{8}{*}{$\begin{array}{l}\text { Cultural } \\
\text { Hubs vs } \\
\text { Non } \\
\text { Cultural } \\
\text { Hubs }\end{array}$} & \multirow{2}{*}{$\begin{array}{l}\text { Import per } \\
\text { capita }\end{array}$} & 181.914281 & 285.7447027 & \multirow{2}{*}{$\mathrm{t}(407)=1.559, \mathrm{p}=.120$} & $\mathrm{No}$ \\
\hline & & & & & & 69.80443568 & 351.9571151 & & \\
\hline & & & & & Payment & 82.26193164 & 175.3676609 & & \\
\hline & & & & & $\begin{array}{l}\text { per } \\
\text { capita }\end{array}$ & 48.08879856 & 169.4410029 & $\mathrm{t}(407)=.975, \mathrm{p}=.330$ & No \\
\hline & & & & & Projects & 0.000322192 & 0.000416972 & & \\
\hline & & & & & $\begin{array}{l}\text { per } \\
\text { capita }\end{array}$ & 0.000233756 & 0.000862651 & $\mathrm{t}(407)=.508, \mathrm{p}=.612$ & No \\
\hline & & & & & Nonprofit & 0.003271259 & 0.001499017 & & \\
\hline & & & & & $\begin{array}{l}\text { per } \\
\text { capita }\end{array}$ & 0.002803625 & 0.001569126 & $\mathrm{t}(407)=1.448, \mathrm{p}=.149$ & No \\
\hline & & & & Cultural & Imnort & 398116.772 & 571078.8585 & $t(13216)=849 n=397$ & $\mathrm{No}$ \\
\hline & & & & Hubs vs & Import & 337670.958 & 503184.6204 & & \\
\hline 9 & PROJECT & Overall & T-Test & & & 224841.5001 & 349274.6561 & & \\
\hline & & & & $\begin{array}{l}\text { Cultural } \\
\text { Hubs }\end{array}$ & Payment & 226596.0204 & 384277.9269 & $\mathrm{t}(304)=-.036, \mathrm{p}=.971$ & No \\
\hline & & & & Cultural & Imnort & 746905.1822 & 687336.0564 & $t(161)=2268 \quad n=025$ & Yes \\
\hline & & Construction & & Hubs vs & & 459017.2351 & 584667.2318 & & \\
\hline 10 & PROJECT & Projects & T-Test & & & 294799.0252 & 342191.7584 & & \\
\hline & & & & $\begin{array}{l}\text { Cultural } \\
\text { Hubs }\end{array}$ & Payment & 296150.6287 & 458249.1707 & $\mathrm{t}(161)=-.015, \mathrm{p}=.988$ & No \\
\hline & & & & Cultural & Jmnort & 229950.9314 & 417595.6796 & $t(78483)=1335 n=186$ & $\mathrm{No}$ \\
\hline & & Service & & Hubs vs & & 147980.2261 & 239387.1805 & & \\
\hline 11 & PROJECT & Projects & T-Test & Non & & 191111.9791 & 350663.8797 & & \\
\hline & & & & $\begin{array}{l}\text { Cultural } \\
\text { Hubs }\end{array}$ & Payment & 117866.9775 & 178729.7751 & $\mathrm{t}(73.615)=1.447, \mathrm{p}=.152$ & No \\
\hline & & & & & $\begin{array}{l}\text { Import per } \\
\text { capita }\end{array}$ & 76.65711571 & 349.0121898 & & \\
\hline 12 & MUNICIPAL & Overall & Correlation & N/A & $\begin{array}{l}\text { Nonprofits } \\
\text { per } \\
\text { capita }\end{array}$ & 0.002832209 & 0.001567179 & $\mathrm{r}(407)=.298, \mathrm{p}<.001$ & Yes \\
\hline 13 & MINUCLD A I & Oyeroll & Correlation & $N / A$ & $\begin{array}{l}\text { Payment } \\
\text { per } \\
\text { Capita }\end{array}$ & 50.17762088 & 169.7859754 & $r(407)-238 n<001$ & Yes \\
\hline 13 & MIUNICIFAL & Overant & 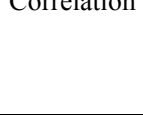 & N/A & $\begin{array}{l}\text { Nonprofits } \\
\text { per } \\
\text { capita }\end{array}$ & 0.002832209 & 0.001567179 & $1(407)-258, p<.001$ & Yes \\
\hline 14 & MINACLDAI & Oromoll & Corrolotion & N/A & $\begin{array}{l}\text { Projects } \\
\text { per capita }\end{array}$ & 0.000239162 & 0.000842168 & $r(407)=280 \quad n<001$ & Yec \\
\hline 14 & MUNICIPAL & Overall & Correlation & $\mathrm{N} / \mathrm{A}$ & $\begin{array}{l}\text { Nonprofits } \\
\text { per capita }\end{array}$ & 0.002832209 & 0.001567179 & $\mathrm{r}(40 /)=.280, \mathrm{p}<.001$ & Yes \\
\hline
\end{tabular}

Source: our calculations 
Table D. The place of the criminal hubs in the projects

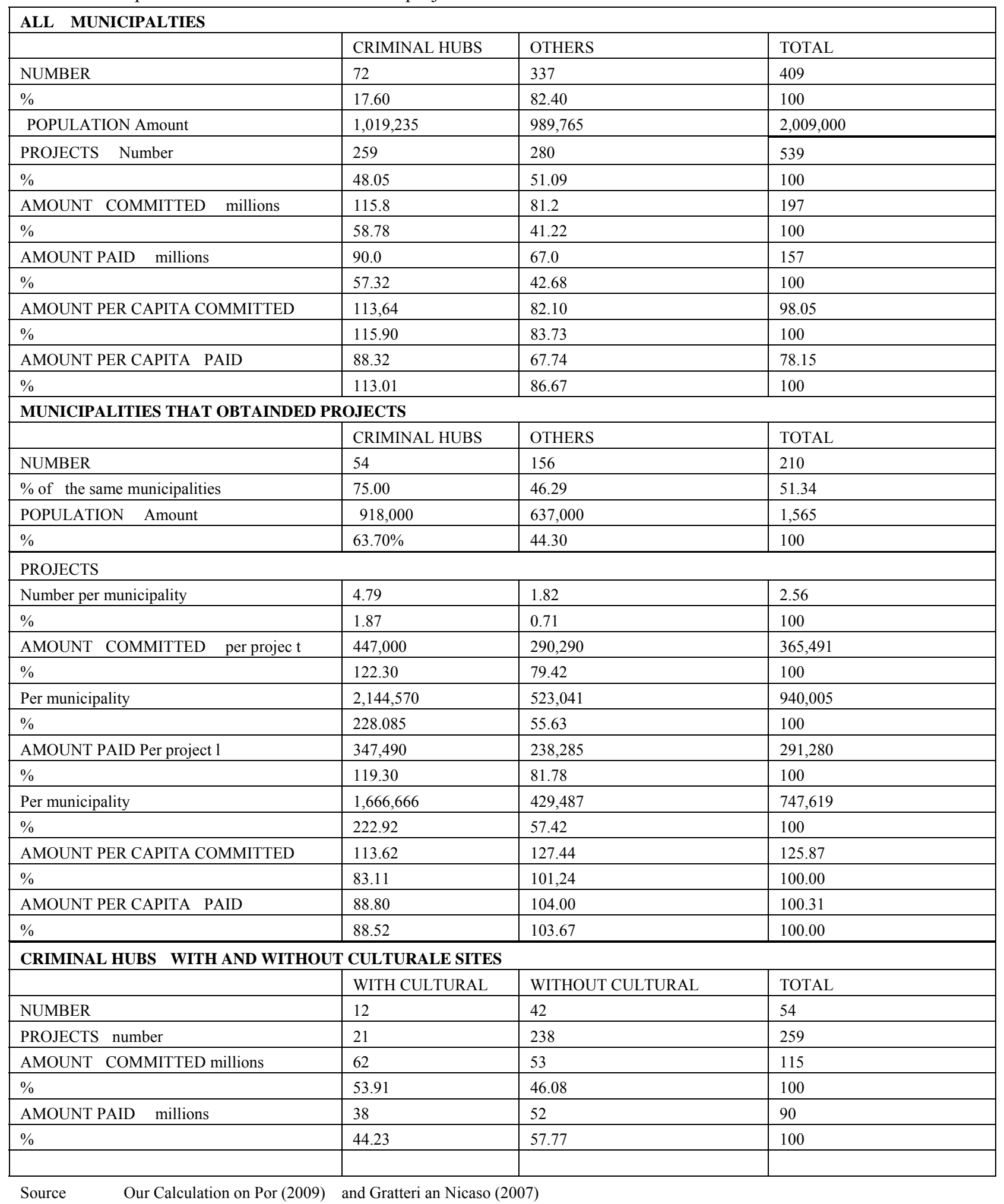


Table E. Test Details for Chiravalloti Municipalities

\begin{tabular}{|c|c|c|c|c|c|c|c|c|c|}
\hline $\begin{array}{l}\text { Test } \\
\#\end{array}$ & Level & Focus & Test & Groups & $\begin{array}{c}\text { Variables } \\
\text { Tested }\end{array}$ & Mean & $\begin{array}{l}\text { Standard } \\
\text { Deviation }\end{array}$ & Conditions & Significance \\
\hline \multirow{2}{*}{19} & \multirow{2}{*}{ MUNICIPAL } & \multirow{2}{*}{ Overall } & \multirow{2}{*}{ Correlation } & \multirow{2}{*}{ N/A } & $\begin{array}{l}\text { Import per } \\
\text { capita }\end{array}$ & 76.65711571 & 349.0121898 & \multirow{2}{*}{$\begin{array}{c}\mathrm{r}(407)=.000 \\
\mathrm{p}=.996\end{array}$} & \multirow{2}{*}{ No } \\
\hline & & & & & $\begin{array}{l}2000 \text { Winning } \\
\text { Party Vote }\end{array}$ & 13.31384714 & 13.31384714 & & \\
\hline \multirow{2}{*}{20} & \multirow{2}{*}{ MUNICIPAL } & \multirow{2}{*}{ Overall } & \multirow{2}{*}{ Correlation } & \multirow{2}{*}{ N/A } & $\begin{array}{l}\text { Payment per } \\
\text { capita }\end{array}$ & 50.17762088 & 169.7859754 & \multirow{2}{*}{$\begin{array}{c}\mathrm{r}(407)=-.005 \\
\mathrm{p}=.912\end{array}$} & \multirow{2}{*}{ No } \\
\hline & & & & & $\begin{array}{l}2000 \text { Winning } \\
\text { Party Vote }\end{array}$ & 13.31384714 & 13.31384714 & & \\
\hline \multirow{2}{*}{21} & \multirow{2}{*}{ MUNICIPAL } & \multirow{2}{*}{ Overall } & \multirow{2}{*}{ Correlation } & \multirow{2}{*}{ N/A } & $\begin{array}{l}\text { Projects per } \\
\text { capita }\end{array}$ & 0.000239162 & 0.000842168 & \multirow{2}{*}{$\begin{array}{c}\mathrm{r}(407)=-.032 \\
\mathrm{p}=.516\end{array}$} & \multirow{2}{*}{ No } \\
\hline & & & & & $\begin{array}{l}2000 \text { Winning } \\
\text { Party Vote }\end{array}$ & 13.31384714 & 13.31384714 & & \\
\hline \multirow{8}{*}{22} & \multirow{8}{*}{ MUNICIPAL } & \multirow{8}{*}{ Overall } & \multirow{8}{*}{ T-Test } & \multirow{8}{*}{$\begin{array}{c}2000 \\
\text { Governmen } \\
\text { t vs Non } \\
2000 \\
\text { Governmen } \\
\text { t } \\
\text { Municipalit } \\
\text { ies } \\
\end{array}$} & \multirow{2}{*}{$\begin{array}{l}\text { Import per } \\
\text { capita }\end{array}$} & 167.8396359 & 320.6699529 & \multirow{2}{*}{$\begin{array}{c}\mathrm{t}(407)=.836 \\
\mathrm{p}=.404\end{array}$} & \multirow{2}{*}{ No } \\
\hline & & & & & & 74.37183951 & 349.7579574 & & \\
\hline & & & & & \multirow{2}{*}{$\begin{array}{l}\text { Payment per } \\
\text { capita }\end{array}$} & 96.32637494 & 259.5348482 & \multirow{2}{*}{$\begin{array}{c}\mathrm{t}(407)=.870 \\
\mathrm{p}=.385\end{array}$} & No \\
\hline & & & & & & 49.0210105 & 167.2529554 & & 100 \\
\hline & & & & & Projects per & 0.000249823 & 0.000376421 & $\mathrm{t}(407)=.040$ & No \\
\hline & & & & & capita & 0.000238895 & 0.000850799 & $\mathrm{p}=.968$ & NO \\
\hline & & & & & Nonprofits per & 0.003309401 & 0.001674112 & $\mathrm{t}(407)=.975$ & No \\
\hline & & & & & capita & 0.00282025 & 0.001564774 & $\mathrm{p}=.330$ & 100 \\
\hline & & & & 2000 & Import & 443840.68 & 693836.001 & $\mathrm{t}(46.385)=.992$ & No \\
\hline & & & & Governmen & 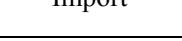 & 340176.78 & 490574.373 & $\mathrm{p}=.361$ & 100 \\
\hline & & & & $\mathrm{t}$ vs Not & & 220925.98 & 450132.405 & & \\
\hline 23 & PROJECT & Overall & T-Test & $\begin{array}{c}2000 \\
\text { Governmen } \\
\mathrm{t} \\
\text { Municipalit } \\
\text { ies }\end{array}$ & Payment & 226923.74 & 362442.18 & $\begin{array}{c}\mathrm{t}(304)=-.095 \\
\mathrm{p}=.924\end{array}$ & No \\
\hline & & & & 2000 & J & 893725.96 & 1001117.65 & $\mathrm{t}(13.75)=1.56$ & No \\
\hline & & & & Governmen & Import & 470339.73 & 551257.75 & $\mathrm{p}=.141$ & No \\
\hline & & Constru & & t vs Not & & 315106.46 & 687320.38 & & \\
\hline 24 & PROJECT & $\begin{array}{c}\text { ction } \\
\text { Projects }\end{array}$ & T-Test & $\begin{array}{c}2000 \\
\text { Governmen } \\
\mathrm{t} \\
\text { Municipalit } \\
\text { ies }\end{array}$ & Payment & 294124.62 & 413018.89 & $\begin{array}{c}\mathrm{t}(161)=.17 \\
\mathrm{p}=.865\end{array}$ & No \\
\hline & & & & 2000 & Imnort & 210566.83 & 272061.58 & $\mathrm{t}(141)=.544$ & No \\
\hline & & & & Governmen & 1іпроль & 172984.72 & 333533.2 & $\mathrm{p}=.587$ & \\
\hline & & & & $\mathrm{t}$ vs Not & & 172091.65 & 261274.78 & & \\
\hline 25 & PROJECT & $\begin{array}{l}\text { Service } \\
\text { Projects }\end{array}$ & T-Test & $\begin{array}{c}2000 \\
\text { Governmen } \\
\mathrm{t} \\
\text { Municipalit } \\
\text { ies }\end{array}$ & Payment & 140605.37 & 262040.23 & $\begin{array}{c}\mathrm{t}(141)=.563 \\
\mathrm{p}=.575\end{array}$ & No \\
\hline
\end{tabular}

Source: our calculations 
Table F. Test Details for Loiero Municipalities

\begin{tabular}{|c|c|c|c|c|c|c|c|c|c|}
\hline $\begin{array}{l}\text { Test } \\
\#\end{array}$ & Level & Focus & Test & Groups & $\begin{array}{c}\text { Variables } \\
\text { Tested }\end{array}$ & Mean & $\begin{array}{l}\text { Standard } \\
\text { Deviation }\end{array}$ & Conditions & Significance? \\
\hline \multirow[b]{2}{*}{26} & \multirow[b]{2}{*}{ MUNICIPAL } & \multirow[b]{2}{*}{ Overall } & \multirow[b]{2}{*}{ Correlation } & \multirow[b]{2}{*}{ N/A } & $\begin{array}{c}\text { Import per } \\
\text { capita }\end{array}$ & 76.65711571 & 349.0121898 & \multirow[b]{2}{*}{$\begin{array}{c}\mathrm{r}(407)=.057 \\
\mathrm{p}=.253\end{array}$} & \multirow[b]{2}{*}{ No } \\
\hline & & & & & $\begin{array}{c}2005 \\
\text { Winning } \\
\text { Vote }\end{array}$ & 10.42941996 & 46.66447433 & & \\
\hline \multirow[b]{2}{*}{27} & \multirow[b]{2}{*}{ MUNICIPAL } & \multirow[b]{2}{*}{ Overall } & \multirow[b]{2}{*}{ Correlation } & \multirow[b]{2}{*}{ N/A } & $\begin{array}{c}\text { Payment } \\
\text { per capita }\end{array}$ & 50.17762088 & 169.7859754 & \multirow[b]{2}{*}{$\begin{array}{c}\mathrm{r}(407)=.026 \\
\mathrm{p}=.597\end{array}$} & \multirow[b]{2}{*}{ No } \\
\hline & & & & & $\begin{array}{c}2005 \\
\text { Winning } \\
\text { Vote } \\
\end{array}$ & 10.42941996 & 46.66447433 & & \\
\hline \multirow[b]{2}{*}{28} & \multirow[b]{2}{*}{ MINICIPAL } & \multirow[b]{2}{*}{ Overall } & \multirow[b]{2}{*}{ Correlation } & \multirow[b]{2}{*}{ N/A } & $\begin{array}{c}\text { Projects } \\
\text { per capita }\end{array}$ & 0.000239162 & 0.000842168 & \multirow[b]{2}{*}{$\begin{array}{c}\mathrm{r}(407)=.027 \\
\mathrm{p}=.590\end{array}$} & \multirow[b]{2}{*}{ No } \\
\hline & & & & & $\begin{array}{c}2005 \\
\text { Winning } \\
\text { Vote } \\
\end{array}$ & 10.42941996 & 46.66447433 & & \\
\hline \multirow{8}{*}{29} & \multirow{8}{*}{ MUNICIPAL } & \multirow{8}{*}{ Overall } & \multirow{8}{*}{ T-Test } & \multirow{8}{*}{$\begin{array}{c}2005 \\
\text { Government } \\
\text { vs Non } 2005 \\
\text { Government } \\
\text { Municipalities }\end{array}$} & Import per & 62.72266221 & 61.86693222 & \multirow{4}{*}{$\begin{array}{c}\mathrm{t}(407)=-.128 \\
\mathrm{p}=.898 \\
\mathrm{t}(407)=-.117 \\
\mathrm{p}=.907\end{array}$} & \multirow{2}{*}{ No } \\
\hline & & & & & \multirow{3}{*}{$\begin{array}{c}\text { capita } \\
\text { Payment } \\
\text { per capita } \\
\end{array}$} & 77.00635013 & 353.2399981 & & \\
\hline & & & & & & 43.96373551 & 56.5475456 & & \multirow{2}{*}{ No } \\
\hline & & & & & & 50.33335735 & 171.6923945 & & \\
\hline & & & & & \multirow{2}{*}{$\begin{array}{c}\text { Projects } \\
\text { per capita }\end{array}$} & 0.000220236 & 0.000264138 & $\mathrm{t}(407)=-.072$ & \\
\hline & & & & & & 0.000239636 & 0.000851751 & $\mathrm{p}=.943$ & No \\
\hline & & & & & Nonprofits & 0.00339345 & 0.001566828 & $\mathrm{t}(407)=1.147$ & \\
\hline & & & & & per capita & 0.002818143 & 0.001566567 & $\mathrm{p}=.252$ & No \\
\hline & & & & 2005 & Import & 352020.5176 & 519751.9532 & $\mathrm{t}(304)=-.027$ & No \\
\hline & & & & Government & Import & 354391.8711 & 523577.0347 & $\mathrm{p}=.978$ & No \\
\hline 30 & PROJECT & Overall & T-Test & vs Not 2005 & & 197861.4785 & 299529.4749 & $\mathrm{t}(304)=-.526$ & \\
\hline & & & & $\begin{array}{c}\text { Government } \\
\text { Municipalities }\end{array}$ & Payment & 230615.8142 & 385423.1785 & $\mathrm{p}=.599$ & No \\
\hline & & & & 2005 & Import & 626591.95 & 766339.108 & $\mathrm{t}(161)=.768$ & No \\
\hline & & & & Government & Import & 495439.5744 & 595270.7453 & $\mathrm{p}=.444$ & No \\
\hline 31 & PROJECT & Projects & T-Test & vs Not 2005 & & 234569.73 & 381277.2516 & $=-.544$ & \\
\hline & & & & $\begin{array}{c}\text { Government } \\
\text { Municipalities }\end{array}$ & Payment & 301691.8319 & 446048.5593 & $\mathrm{p}=.587$ & No \\
\hline & & & & 2005 & Imnort & 214734.8014 & 262330.2794 & $\mathrm{t}(141)=.663$ & No \\
\hline & & & & Government & Import & 171643.1077 & 335718.9155 & $\mathrm{p}=.528$ & No \\
\hline 32 & PROJECT & $\begin{array}{l}\text { Service } \\
\text { Projects }\end{array}$ & T-Test & vs Not 2005 & & 179507.3529 & 255335.3941 & & \\
\hline & & & & $\begin{array}{c}\text { Government } \\
\text { Municipalities }\end{array}$ & Payment & 138526.0173 & 263161.6432 & $\mathrm{p}=.459$ & No \\
\hline
\end{tabular}

Source: our calculations

Table G. Criminal Hubs

\begin{tabular}{|l|c|c|c|c|c|c|}
\hline Municipality & Populations & Cultural sites & Non-profit & Projects & Payments & Commitment \\
\hline Africo (RC) & 3,465 & 0 & 18 & 0 & 0 & 0 \\
\hline Amantea (CS) & 13,268 & 0 & 30 & 3 & $516,377.36$ & $814,370.28$ \\
\hline Bagnara Calabra (RC) & 11,230 & 0 & 34 & 1 & $95,220.11$ & $95,220.11$ \\
\hline Bianco (RC) & 4,047 & 0 & 16 & 0 & 0 & 0 \\
\hline Botricello (CZ) & 4,586 & 0 & 7 & 0 & 0 & 0 \\
\hline Bova Marina (RC) & 3,967 & 0 & 23 & 6 & $3,676,273.3$ & $5,273,978.4$ \\
\hline Bova (RC) & 474 & 0 & 6 & 9 & $2,817,149.8$ & $4,720,996.4$ \\
\hline Bovalino (RC) & 8,358 & 0 & 39 & 4 & $465,166.55$ & $1,099,912.5$ \\
\hline Bruzzano Zeffirio (RC) & 1,401 & 0 & 3 & 0 & 0 & 0 \\
\hline Careri (RC) & 2,443 & 0 & 4 & 0 & 0 & 0 \\
\hline Casignana (RC) & 775 & 0 & 3 & 2 & $2,710,353.5$ & $2,710,353.5$ \\
\hline Cassano allo Ionio (CS) & 17,565 & 2 & 37 & 8 & $4,130,568.3$ & $4,505,924.3$ \\
\hline Castrovillari (CS) & 22,389 & 0 & 78 & 3 & $169,995.97$ & $190,975.97$ \\
\hline Catanzaro (CZ) & 95,251 & 0 & 535 & 35 & $10,128,753$ & $12,005,666$ \\
\hline Cetraro (CS) & 10,333 & 0 & 19 & 1 & $14,999.59$ & $14,999.59$ \\
\hline Cirò Marina (KR) & 13,987 & 0 & 26 & 0 & 0 & 0 \\
\hline Cittanova (RC) & 10,675 & 0 & 27 & 0 & 0 & 0 \\
\hline Condofuri (RC) & 5,055 & 0 & 6 & 4 & $174,792.94$ & $761,156.57$ \\
\hline Corigliano Calabro (CS) & 38,241 & 1 & 71 & 6 & $954,893.58$ & $1,258,881.3$ \\
\hline Cosenza (CS) & 72,998 & 2 & 477 & 18 & $10,858,300$ & $15,067,260$ \\
\hline
\end{tabular}




\begin{tabular}{|c|c|c|c|c|c|c|}
\hline Crotone (KR) & 60,010 & 2 & 384 & 14 & $10,998,600$ & $11,095,193$ \\
\hline Cutro (KR) & 10,829 & 0 & 11 & 1 & 10,000 & 10,000 \\
\hline Filadelfia (VV) & 6,283 & 0 & 15 & 1 & 10,000 & 10,000 \\
\hline Fuscaldo (CS) & 8,323 & 0 & 25 & 2 & $639,647.39$ & $681,497.48$ \\
\hline Galatro (RC) & 2,307 & 0 & 2 & 0 & 0 & 0 \\
\hline Gioia Tauro (RC) & 17,762 & 0 & 55 & 3 & $879,815.33$ & $1,117,466.6$ \\
\hline Gioiosa Ionica (RC) & 7,044 & 0 & 21 & 3 & $205,452.7$ & $205,452.71$ \\
\hline Guardavalle (CZ) & 5,315 & 0 & 7 & 1 & $495,102.38$ & $495,102.38$ \\
\hline Lamezia Terme (CZ) & 70,501 & 1 & 228 & 12 & $6,854,918.8$ & $7,299,960.3$ \\
\hline Laureana di Borrello (RC) & 5,709 & 0 & 13 & 0 & 0 & 0 \\
\hline Limbadi (VV) & 3,630 & 0 & 4 & 0 & 0 & 0 \\
\hline Locri (RC) & 12,997 & 3 & 65 & 8 & $3,465,832.6$ & $4,476,272.1$ \\
\hline Mammola (RC) & 3,389 & 0 & 8 & 2 & $651,763.48$ & $707,760.02$ \\
\hline $\begin{array}{l}\text { Marina di Gioiosa } \\
\text { Ionica (RC) }\end{array}$ & 6,440 & 0 & 19 & 1 & 6,000 & 6,000 \\
\hline Melicucco (RC) & 4,996 & 0 & 13 & 0 & 0 & 0 \\
\hline Melito di Porto Salvo (RC) & 10,506 & 0 & 39 & 5 & $1,001,660.8$ & $1,603,608.3$ \\
\hline Mesoraca (KR) & 7,125 & 0 & 20 & 2 & $51,666.67$ & $93,333.33$ \\
\hline Mileto (VV) & 7,157 & 1 & 33 & 2 & $324,767.58$ & $339,501.24$ \\
\hline Monasterace (RC) & 3,426 & 1 & 16 & 1 & $282,436.79$ & 300,000 \\
\hline Montebello Ionico (RC) & 6,922 & 0 & 16 & 0 & 0 & 0 \\
\hline Oppido Mamertina (RC) & 5,559 & 0 & 23 & 4 & $2,091,343.2$ & $3,613,740.6$ \\
\hline Palizzi (RC) & 2,709 & 0 & 12 & 1 & $474,225.96$ & 610,000 \\
\hline Palmi (RC) & 19,435 & 1 & 45 & 5 & $2,356,504.3$ & $3,847,090.1$ \\
\hline Paola (CS) & 17,195 & 0 & 51 & 4 & $177,080.93$ & $338,300.98$ \\
\hline Petilia Policastro (KR) & 9,594 & 0 & 28 & 1 & 20,000 & 20,000 \\
\hline Petronà $(\mathrm{CZ})$ & 3,010 & 0 & 5 & 0 & 0 & 0 \\
\hline Platì (RC) & 3,823 & 0 & 15 & 0 & 0 & 0 \\
\hline Polistena (RC) & 11,591 & 0 & 30 & 4 & $277,664.95$ & $747,215.03$ \\
\hline Reggio di Calabria (RC) & 180,353 & 3 & 656 & 28 & $6,757,632.4$ & $7,950,883.4$ \\
\hline Rizziconi (RC) & 7,650 & 0 & 25 & 0 & 0 & 0 \\
\hline Rocca di Neto (KR) & 5,614 & 0 & 13 & 0 & 0 & 0 \\
\hline Roccella Ionica (RC) & 6,762 & 0 & 33 & 4 & $5,988,575.9$ & $6,066,275.9$ \\
\hline Roghudi (RC) & 1,365 & 0 & 0 & 1 & $220,414.71$ & 494,000 \\
\hline Rosarno (RC) & 15,051 & 0 & 15 & 3 & $485,869.57$ & $1,253,928$ \\
\hline San Ferdinando (RC) & 4,339 & 0 & 11 & 1 & 90,000 & 90,000 \\
\hline San Gregorio d'Ippona (VV) & 2,338 & 0 & 4 & 2 & $373,780.09$ & $373,780.09$ \\
\hline San Lorenzo (RC) & 3,357 & 0 & 8 & 2 & $518,201.77$ & $908,805.1$ \\
\hline San Luca (RC) & 4,106 & 0 & 7 & 1 & $416,165.48$ & $416,165.48$ \\
\hline San Lucido (CS) & 5,906 & 0 & 16 & 1 & $14,997.28$ & 15,000 \\
\hline Seminara (RC) & 3,352 & 0 & 12 & 1 & $452,021.35$ & 463,480 \\
\hline Serra San Bruno (VV) & 7,068 & 1 & 18 & 4 & $371,409.61$ & $1,759,943.8$ \\
\hline Siderno (RC) & 1,6734 & 0 & 34 & 2 & 0 & 55,000 \\
\hline Sinopoli (RC) & 2,329 & 0 & 3 & 1 & $134,797.34$ & 22,5000 \\
\hline Soriano Calabro (VV) & 3,068 & 0 & 14 & 2 & $319,896.86$ & $319,896.86$ \\
\hline Staiti (RC) & 395 & 0 & 3 & 1 & $254,919.87$ & 377,000 \\
\hline Stignano (RC) & 1,373 & 0 & 1 & 0 & 0 & 0 \\
\hline Stilo (RC) & 2,816 & 1 & 7 & 1 & $49,724.21$ & $1,250,000$ \\
\hline Strongoli (KR) & 6,107 & 0 & 9 & 3 & $424,873.16$ & $1,676,234.4$ \\
\hline Taurianova (RC) & 15,799 & 0 & 30 & 0 & 0 & 0 \\
\hline Vibo Valentia (VV) & 33,957 & 2 & 155 & 12 & $5,292,731.9$ & $5,526,586.2$ \\
\hline Villa San Giovanni (RC) & 13,119 & 0 & 53 & 3 & $136,841.17$ & $136,841.17$ \\
\hline Zungri (VV) & 2,182 & 0 & 5 & 2 & $216,402.33$ & $310,744.11$ \\
\hline Total & $1,019,235$ & 21 & 3,794 & 252 & $90,506,584$ & $115,806,753$ \\
\hline
\end{tabular}

Source: Gratteri and Nicaso (2007) for the list of criminal hubs and POR (2009) for the data 